Meta

Journal des traducteurs

Translators' Journal

\title{
Coding Betweenness in Swedish and Norwegian Translations from English
}

\section{Gudrun Rawoens et Thomas Egan}

Volume 60, numéro 3, décembre 2015

URI : https://id.erudit.org/iderudit/1036144ar

DOI : https://doi.org/10.7202/1036144ar

Aller au sommaire du numéro

Éditeur(s)

Les Presses de l’Université de Montréal

ISSN

0026-0452 (imprimé)

1492-1421 (numérique)

Découvrir la revue

Citer cet article

Rawoens, G. \& Egan, T. (2015). Coding Betweenness in Swedish and Norwegian Translations from English. Meta, 60(3), 576-598.

https://doi.org/10.7202/1036144ar
Résumé de l'article

Cet article examine de quelle façon la notion sémantique de betweenness est codée dans les traductions suédoises et norvégiennes de textes sources anglais. L'étude a pour assise que les expressions originales de betweenness fondées sur la préposition between constituent un tertium comparationis viable pour la traduction de cette forme en suédois et en norvégien. Nous classifions d'abord les occurrences de between repérées dans les textes sources anglais du English-Swedish Parallel Corpus (ESPC) et du English-Norwegian Parallel Corpus (ENPC) en fonction du rôle sémantique des repères dans les prédicats, puis nous analysons les traductions. L'article ce concentre sur les parallèles établis entre les deux ensembles de traductions étudiées, et non sur les correspondances entre l'original anglais et les traductions en suédois et en norvégien. Pour ce faire, nous comparons les façons de traduire, en suédois et en norvégien, les différentes significations de between repérées dans les données sources. L'analyse démontre que le suédois et le norvégien se ressemblent dans la façon de coder les divers sens de between. La dernière partie de l'étude présente un point de vue complémentaire fondé sur la comparaison du nombre d'occurrences des équivalents les plus communs de between, soit mellan en suédois et mellom en norvégien, dans des contextes où ces termes ne sont pas employés pour traduire between dans les textes sources anglais. Cette approche révèle que même lorsque between n'est pas présent dans les textes originaux, les traducteurs emploient les prépositions apparentées dans plus de $25 \%$ des cas.
Ce document est protégé par la loi sur le droit d'auteur. L'utilisation des services d'Érudit (y compris la reproduction) est assujettie à sa politique d'utilisation que vous pouvez consulter en ligne.

https://apropos.erudit.org/fr/usagers/politique-dutilisation/ 


\title{
Coding Betweenness in Swedish and Norwegian Translations from English
}

\author{
GUDRUN RAWOENS \\ Universiteit Gent, Ghent, Belgium \\ gudrun.rawoens@gmail.com \\ THOMAS EGAN \\ Høgskolen i Hedmark, Hamar, Norway \\ Thomas.Egan@hihm.no
}

\begin{abstract}
RÉSUMÉ
Cet article examine de quelle façon la notion sémantique de betweenness est codée dans les traductions suédoises et norvégiennes de textes sources anglais. L'étude a pour assise que les expressions originales de betweenness fondées sur la préposition between constituent un tertium comparationis viable pour la traduction de cette forme en suédois et en norvégien. Nous classifions d'abord les occurrences de between repérées dans les textes sources anglais du English-Swedish Parallel Corpus (ESPC) et du English-Norwegian Parallel Corpus (ENPC) en fonction du rôle sémantique des repères dans les prédicats, puis nous analysons les traductions. L'article ce concentre sur les parallèles établis entre les deux ensembles de traductions étudiées, et non sur les correspondances entre l'original anglais et les traductions en suédois et en norvégien. Pour ce faire, nous comparons les façons de traduire, en suédois et en norvégien, les différentes significations de between repérées dans les données sources. L'analyse démontre que le suédois et le norvégien se ressemblent dans la façon de coder les divers sens de between. La dernière partie de l'étude présente un point de vue complémentaire fondé sur la comparaison du nombre d'occurrences des équivalents les plus communs de between, soit mellan en suédois et mellom en norvégien, dans des contextes où ces termes ne sont pas employés pour traduire between dans les textes sources anglais. Cette approche révèle que même lorsque between n'est pas présent dans les textes originaux, les traducteurs emploient les prépositions apparentées dans plus de $25 \%$ des cas.
\end{abstract}

\section{ABSTRACT}

This paper examines the way in which the semantic notion of 'betweenness' is coded in Swedish and Norwegian translations of the same English source texts. The study takes its starting point in the contention that the original English expressions of 'betweenness' containing the preposition between constitute a viable tertium comparationis for translations of that form into the other two languages. A classification of all occurrences of between in the English source texts in The English-Swedish Parallel Corpus (ESPC) and The English-Norwegian Parallel Corpus (ENPC) in terms of the semantic role of the landmarks in the predications is followed by an analysis of the translations, both congruent and divergent. The primary focus, however, is not on the correspondences between the English original and its translations into Swedish and Norwegian, but on the parallels between the two sets of translations. To this end comparisons are drawn between the Swedish and Norwegian renderings of the various meanings of between in the source data. The analysis shows that Swedish and Norwegian resemble one another closely in the means employed to code the various senses of between. The last part of the study offers a complementary perspective in comparing occurrences of the most common translation equivalents of between, mellan in Swedish and mellom in Norwegian, in contexts where they do not translate between in the English source texts. This approach 
reveals that, despite the lack of between in the original texts, the two sets of translators both employ the cognate prepositions in over $25 \%$ of cases.

\section{MOTS-CLÉS/KEYWORDS}

notion sémantique de betweenness, étude de traduction, approche à trois textes, fondé sur corpus

semantic notion of betweenness, translation study, 3-text approach, corpus-based

\section{Introduction: Tertia comparationis and 3-text translation corpora}

The aim of the study reported on in this article is to provide an empirically based account of the similarities and differences between the two closely related languages Swedish and Norwegian in their codings of the various types of 'between' relationships. To the best of our knowledge, this is the first study of its kind of these phenomena. Indeed it is only in the last couple of decades that scholars have had access to the sort of comparable corpora that serve to render such studies feasible. The feasibility of a comparative study like ours based on translations of individual linguistic items depends, of course, on the degree to which the translators reproduce the sense of the original. It is in measuring the degree of correspondence that the results of our translation-based contrastive study can contribute to the related field of translation studies.

The great increase in the number of contrastive linguistic studies and translation studies fuelled by the availability of parallel and translation corpora has been accompanied by a range of theoretical discussions on the aims and methodology involved in contrastive analyses. We will touch on three aspects of these discussions in the following.

In the first place one aspect that has been subject to much discussion is the question of the very aims of contrastive analysis. As has been pointed out by various scholars, the aims of contrastive analysis are not only to highlight similarities and differences between the languages studied - an interlingual perspective - but also to reveal properties contained in each of the individual languages - an intralingual perspective (Johansson 1975: 15; Aijmer and Altenberg 1996: 12; Johansson 2000: 4). Contrastive studies may also take a more theoretical or more empirical perspective depending on whether the primary aim is to study the language system (langue) or language use (parole). Of course, the two approaches are by no means mutually exclusive, as pointed out by Altenberg and Granger:

The aim is to account for both language systems and language use, i.e. the task is not only to identify translation equivalents and 'systematic' correspondences between categories in different languages, but to specify to what extent and in what respect they express 'the same thing' and where similarities and differences should be located in a model of linguistic description. (Altenberg and Granger 2002: 18)

On the basis of the Swedish and Norwegian translations of phrases containing between, we aim to identify what Altenberg and Granger refer to as "systematic correspondences." We employ the term 'translation equivalents' for these systematic correspondences between items in a source and target language (the two langues), and employ the term 'translation correspondences' for matches between individual tokens (on the level of parole). Finally, we use the term 'translation parallels' for 
systematic correspondences in the two target languages (see Johansson 2001; 2007 for similar usage).

A second point that has been discussed in the literature on contrastive analysis has centered around the notion of tertium comparationis, which is a non-linguistic basis for a contrastive analysis that constitutes a kind of common ground for the elements that are being compared (comparatum and comparandum): or to put it differently "the background of sameness against which differences can be viewed and described" (Johansson 2007: 39). Descriptions of tertium comparationis such as "a vital ingredient" (James 1980: 90) or the "most fundamental concept" (Krzeszowski 1990: 15) underline its importance in contrastive studies:

It has been a commonplace to point out that no comparison can be made between any two entities without a frame of reference provided by a third term of some kind, and that decisions about equivalence are ipso facto decisions about the tertium comparationis. (Chesterman 1998: 29)

The choice of a viable tertium comparationis depends on the type and topic of the study in question. In phonological studies, for instance, the International Phonetic Alphabet (IPA) chart can serve as a tertium comparationis while in lexical studies, the tertium comparationis can consist of a set of semantic components (James 1980: 169-175). In grammatical studies, the tertium comparationis may be a grammatical structure or translation equivalence (James 1980: 169; see also Rawoens 2008). In contrastive studies involving two or more languages, the choice of a tertium comparationis can be semasiologically or onomasiologically motivated, depending on whether the common ground of comparison is made up of similar word forms or syntactic structures on the one hand, or whether the common ground is semantically and/or pragmatically motivated on the other. If there is no common ground, that is, if the languages involved do not resemble each other in any respect, no tertium comparationis can be established, as is pointed out by Krzeszowski:

All comparisons involve the basic assumption that the objects to be compared share something in common, against which differences can be stated. This common platform of reference is called tertium comparationis. Moreover, any two or more objects can be compared with respect to various features and, as a result, the compared objects may turn out to be similar in some respects but different in others. (Krzeszowski 1990: 15)

In contrastive studies relying on translation data, translation equivalence is usually taken as evidence of semantic equivalence. As such, it is assumed that there exists a viable tertium comparationis in the form of a meaning component common to both the source expression and its translation (see Egan 2013a). In this paper the choice of tertium comparationis is onomasiologically motivated in that the focus is on semantic/pragmatic, rather than syntactic equivalence (even though these may coincide). More specifically, the tertium comparationis is the semantic notion of 'betweenness' and how it is encoded in Swedish and Norwegian.

When using translation data in contrastive studies, one must always bear in mind the possibility that translation effects may skew the results of the comparison. There is no doubt that translated texts may differ in some respects from original texts. Indeed this is the reason why we prefer to compare two sets of translations rather than an original text and a translation. Translated texts may bear traces of so called "translationese," a term coined by Gellerstam (1996: 54) to denote a "language 
variety" of a particular language (in translated form) which carries "unmistakable fingerprints" of the source language (in this particular study Gellerstam studied the Swedish language used in translations from English). These "unmistakable footprints" are referred to as "translation effects" (Johansson 2007: 32). Translated texts may also display other traits that are seen as typical, both at the lexical or syntactic level (see James 1980: 117-118; Aijmer and Altenberg 1996: 13; Granger 1996: 48-49; Teubert 1996: 247; Johansson 1998: 5; Mauranen 2005). However, in the present study, not only are translations being compared to other translations, all three languages, English, Swedish and Norwegian are also typologically similar. There are thus not many differences in the syntax of English on the one hand and Swedish and Norwegian, on the other, that would necessitate the choice of divergent grammatical constructions on the part of the translators. So similar are the two languages that we see no a priori reason to expect to find more tokens displaying translation effects in one target language than the other. Moreover, if one language did contain an excess of such tokens, this might in itself point to a difference between the two languages worthy of further exploration.

The third and final issue that we will mention here is the question of the empirical basis in contrastive analysis. In contrastive studies a number of different approaches may be taken, related to the kind of corpora used. One possibility is to rely on a parallel corpus of original texts, which may be said to make up a comparable corpus (see Altenberg and Granger 2002: $8^{1}$ ). Relying on this corpus type, one can ensure to some extent that one is dealing with similar text types but one may run into problems establishing a tertium comparationis. A second possibility is to use a translation corpus, by which we mean a corpus containing original texts in at least one language and translations of these texts into one or more languages. In choosing this option, one is on safer ground with respect to the tertium comparationis, but faces the problems inherent in operating with two different sets of texts, an original (source) and a translated (target) text.

Krzeszowski (1990: 25-26) coined the term 2-text to refer to either translation corpora (containing source texts and translations) or parallel (that is, comparable) corpora. The availability of multilingual corpora allows us to operate with the concept of 3-text, which brings us to a third possible approach in contrastive studies (see Egan 2013a). In a 3-text corpus, expressions in a source language serve as potential tertia comparationis for their translations into two other languages. ${ }^{2}$ The advantage of a 3-text approach, which is employed in the present study, is that one can ensure the similarity of text types by comparing two translated texts, while retaining a reliable tertium comparationis in the form of the original text.

Before proceeding to a presentation and examination of our data, there is one point that should be aired regarding the suitability of the 3-text approach employed in this study. The question is a practical one and concerns the possibility that one or more of either the Swedish or Norwegian translators made use of a prior translation into the other language. Given the level of competence in English to be expected of translators into Swedish and Norwegian, it seems to us unlikely that any of them would have felt the need to consult a prior translation into the other language. Nor did we find any obvious text-internal evidence of the sort that could give rise to the suspicion of one translator's having consulted another translation. 
The structure of the paper is as follows. In Section 2 we present our aims, our data and the methodology employed. The semantics of the English preposition between are described in Section 3. Section 4 gives an overview of the translation equivalents as they occur in the Swedish and Norwegian translated texts, followed by a close scrutiny of the congruent and divergent translations. In Section 5 we compare and contrast tokens which do not translate English between but which nevertheless contain the most frequent translation equivalents of this lexeme, mellan in Swedish and mellom in Norwegian. The paper rounds off with a summary and some conclusions in Section 6.

\section{Aims, data and methodology}

The aim of the present study, as stated in the previous section, is to compare and contrast codings of the 'between' relationship in Swedish and Norwegian. We do this, firstly, by exploring the degree of overlap between the equivalents of the English preposition between in Swedish and Norwegian, focusing both on similarities and differences (see Chesterman 1998: 52), and secondly by exploring the use of the two dictionary equivalents (or default translation equivalents) of between, namely mellan in Swedish and mellom in Norwegian in contexts where they do not translate between.

Egan (2013b), which contains the results of a study of English, French and German translations of the Norwegian preposition mellom in the the NorwegianEnglish-French-German part of the Oslo Multilingual Corpus, ${ }^{3}$ shows that there is a considerable degree of overlap between the translators' use of between, entre and $\underline{\text { zwischen }}$. Indeed, as many as $46 \%$ of tokens of mellom are translated by all three. We may compare this to a total of just $19 \%$ for translations of Norwegian gjennom by all three of through, à travers and durch (Egan 2013b), and a total of 34\% for translations of the English preposition among(st) by Swedish bland and Norwegian blant (Rawoens and Egan 2014).

Given the common historical origin and present-day similarity in vocabulary and grammar of Swedish and Norwegian, our initial hypothesis was that translations of English between into these two languages would result in considerable overlap in the use of Swedish mellan and Norwegian mellom. We test this hypothesis in Section 4.

The empirical data for the present study are taken from The English-Swedish Parallel Corpus (ESPC) (Aijmer, Altenberg et al. 1996: 79-80) and The EnglishNorwegian Parallel Corpus (ENPC) (Johansson 1998; Johansson, Ebeling et al. 2002) containing English originals and their translations into Swedish and Norwegian respectively. The corpora also contain Swedish and Norwegian originals and their translations into English. We did not consult these texts since they could not, by their very nature, provide us with the sort of tertium comparationis we were looking for. The corpora are comparable in size (roughly 2.8 million words for the ESPC, 2.7 million words for the ENPC) and content. Both contain text extracts taken from a variety of fiction and non-fiction works the full details of which can be found on the respective websites. ${ }^{4}$ We did not analyze the fiction and non-fiction texts separately, since the same texts in both registers are translated into the two languages.

We used the overlapping texts in the two corpora only (roughly $80 \%$ of both corpora $^{5}$ ), that is, the English source texts which are common to both corpora and 
to both sets of translations. The tokens were first classified independently by the two authors before bringing the categorizations together and discussing tokens which we had categorized differently in order to arrive at a consensus. The study is carried out according to the procedure proposed by Krzeszowski (1990: 35-46). A typical contrastive analysis consists of the following stages: I. Description, II. Juxtaposition, III. Comparison (see also Chesterman (1998: 54) for a model in which a few additional substages are distinguished).

In the first stage, we describe the occurrences of the English between in the source texts and classify them in terms of the landmark of the preposition. This classification is described in Section 3. Next, we classify the Swedish and Norwegian translations as congruent (containing a similar preposition or other preposition) or divergent (containing a paraphrase, that is to say, non-prepositional), or as not translated. Following this first observation and description of the data at hand, the data from the two language sets are brought together with a view to comparing them.

In the second stage, contrasting Swedish mellan and Norwegian mellom in the translated texts in contexts where they do not translate between, we composed lists with these occurrences, excluding instances which translated between in the English source texts. We classified these occurrences in terms of the landmarks of the preposition mellan/mellom as they occurred in the translations and again labelled the relation to the corresponding expression as either congruent (containing a preposition phrase), divergent or zero.

\section{The English preposition between}

We distinguish eight senses of the preposition between (375 tokens) as found in the English corpus data in the subsets of the ESPC and ENPC used here. Each of these is illustrated below. The main uses of the English preposition between are categorized according to the semantic role of the landmark of the preposition (see Langacker 1987: 216; Lindstromberg 2010: 6 for this use of 'landmark' for the semantic pole of the prepositional complement). ${ }^{6}$

In the sentence in (1) the two women are agentive in the struggle between them. We therefore categorize the landmark in this token as Agent.

(1) This was an ancient battle between the two women (GN1) ${ }^{7}$

The following two senses are characterized as Setting, with the landmark coding a physical setting (Location) or a temporal one (Time), as illustrated in (2) and (3) respectively.

(2) A vicarage with a high green roof and an attic; a canal of turgid water between house and stark white church. (BR1)

(3) Jim Rawlings spent the hour between nine and ten that night sitting in another, smaller rented car outside Fontenoy House. (FF1)

The landmark illustrated in (4) is labelled Theme (Comparison) since the predication of a distinction between the two items (both Themes) in both landmarks implies an act of comparison between them.

(4) When did distinction between black and real black, between himself and them, fade, for the schoolteacher? (NG1) 
Example (5) also contains the element Theme, but unlike in (4) no act of comparison between the Themes is implied. Instead it is implied that there is some sort of relationship (in this case a causal relationship) between the two items in the landmark. We classify tokens like (5) as coding Theme (Relationship).

(5) Such grass-fed beef is suitable for the manufacture of hamburgers, so there is a direct link between the destruction of the forests in Central and Latin America and the desire of Northerners to eat cheap hamburgers. (LT1)

In predications such as (6), the two items in the landmark code points on a scale. We have employed the label Scale for these.

(6) Pierrot had told us that the table would weigh between six and eight hundred pounds. (PM1)

Our material also contains a number of tokens in which the landmark of between codes an Experiencer. In (7), for instance, they experience the tension which is sensed by the sentential subject.

(7) She could sense the tension quivering between them. (PDJ1)

Finally, there are three tokens which encode the distribution of some item or other between the referents of the landmark. Thus in (8) we are not told which of the two people concerned has one parent alive. The property of having a living parent is true of one or other of them. We have labelled this sort of usage Distribution.

(8) Only one parent out of four between us. (JB1)

For obvious reasons, we omitted from our analysis occurrences which were not translated into either Swedish or Norwegian, or both. Of a total of 375 tokens of between in the original English texts common to both corpora, 29 occur in phrases that are not translated into Swedish (as in (9)) and 18 in phrases that are not translated into Norwegian. Eight of these 29 tokens are not translated into either language. In example (9), for instance, the underlined phrase in English is omitted by the Swedish translator.

(9) Derogations may be made from Articles 3, 4, 5, 8 and 16 by means of collective agreements or agreements concluded between the two sides of industry at national or regional level or, in conformity with the rules laid down by them, by means of collective agreements or agreements concluded between the two sides of industry at a lower level. (EEA1)

SW: Avvikelser får göras från artiklarna 3, 4, 5, 8 och 16 genom kollektivavtal på nationell eller regional nivå eller genom kollektivavtal på en lägre nivå om det tillåts genom sådana avtal. (EEA1TS) ${ }^{8}$

NW: Artikkel 3, 4, 5, 8 og 16 kan fravikes ved tariffavtaler eller avtaler inngått mellom partene $i$ arbeidslivet på nasjonalt eller regionalt plan, eller, $i$ samsvar med reglene fastsatt av disse partene i arbeidslivet, ved tariffavtaler eller avtaler inngått mellom parter $i$ arbeidslivet på et lavere nivå. (EEA1TN)

It may be of interest to note that (9) is one of eleven examples in which "collective agreements" or "agreements between the two sides" is rendered in Swedish as "kollektivavtal" and more fully in Norwegian as "tariffavtaler eller avtaler inngått mellom partene." We think it likely that the Swedish translator has left out the between predication in these tokens as superfluous or redundant. In other words the Swedish example may be seen as an example of implicitation (see Becher 2011a). 
Having omitted the tokens that are not translated into one or other language, or both of them, we are left with a total of 336 tokens in the original English texts which were assigned to one of the eight classes on the basis of the semantic type of predication coded by the preposition. Table 1 shows the distribution of between grouped according to the various semantic categories of the phrases in which they occur in the English original texts. The figures show that Setting (Location) is by far the most frequently occurring landmark, followed by a middle group of four landmarks - from Theme (Relationship) to Setting (Time) - which are comparable in size. The bottom group in the table contains Scale, Experiencer and Distribution, the last one appearing to occur only marginally.

TABLE 1

Tokens per semantic category of between translated into both Swedish and Norwegian

\begin{tabular}{|l|c|}
\hline Type of phrase & No. of tokens \\
\hline Setting (Location) & 113 \\
\hline Theme (Relationship) & 58 \\
\hline Agent & 54 \\
\hline Theme (Comparison) & 42 \\
\hline Setting (Time) & 37 \\
\hline Scale & 17 \\
\hline Experiencer & 12 \\
\hline Distribution & 3 \\
\hline Total & $\mathbf{3 3 6}$ \\
\hline
\end{tabular}

\section{Translation equivalents of English between: an overview}

Following the classification of the various senses of between in the English source texts, we proceed to examine the translation patterns employed by the two sets of translators. Figure 1 gives an overview of the Swedish and Norwegian translation equivalents of the English between. As mentioned earlier, of the total of 375 tokens of between in the corpora, 336 are translated into both Swedish and Norwegian - the category Zero translation, which appears in Figure 1 (representing the 29 Swedish and 18 Norwegian instances of omission of translation mentioned in the previous section and illustrated in example 12) is not taken into account in the rest of the paper.

\section{FIGURE 1}

Swedish and Norwegian translation equivalents of English between

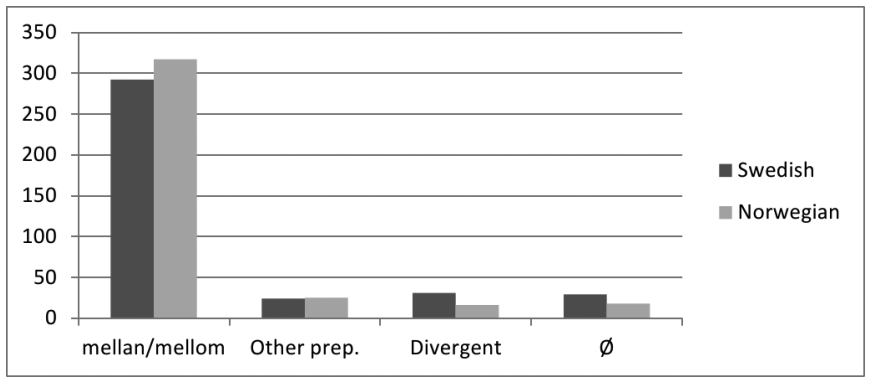


The remaining 336 tokens are classified as syntactically congruent or divergent (see Johansson 2007: 24). Congruent translations feature a translation with a prepositional coding of the landmark of between (either mellan/mellom or another preposition or prepositional phrase) whereas divergent translations are non-prepositional constructions - these may, for instance, consist of a paraphrase in the form of a subordinate clause.

As appears from Figure 1, the overwhelming majority of the translations in both Swedish and Norwegian make use of the preposition mellan/mellom (this group contains 292 SW/317NW tokens), whereas the groups featuring other prepositions or divergent patterns are relatively small (containing 24SW/25NW and 31 SW/16 NW tokens respectively). In what follows, we will have a closer look at each of these three modes of translation.

\subsection{Translations by $\underline{\text { mellan} / \mathrm{mellom}}$}

Translations by mellan and mellom constitute the largest group of translations of between representing an overlap of $78 \%$ for the two forms. We will now illustrate each landmark type translated by both prepositions (see Figure 2 for an overview of the internal distribution). To begin with Setting (Location) landmarks, which are the most common of our eight classes, these may either be used to situate objects, as in (10) or to code the location of motion events, as in (11). Both are commonly translated by mellan/mellom. Indeed $85 \%$ of the tokens are translated by both forms.

(10) There were thick bushes and low trees between the houses. (BO1)

SW: Det fanns tjocka buskar och låga träd mellan husen. (BO1TS)

NW: Mellom husene vokste tette busker og lave troer (BO1TN)

(11) They had crept between her sheets .... (GN1)

SW: De hade smugit sig in mellan lakanen .... (GN1TS)

NW: De hadde krøpet inn mellom lakenene .... (GN1TN)

Agent landmarks are also commonly translated by both mellan and mellom (in $81.5 \%$ of all cases), as illustrated in (12).

(12) There were frequent clashes between the various ethnic groups, usually over jobs. (RF1)

SW: Det kom ofta till sammanstötningar mellan de olika etniska grupperna, vanligtvis om arbeten. (RF1TS)

NW: Det forekom hyppige sammenstøt mellom de forskjellige etniske gruppene, som regel på grunn av jobber. (RF1TN)

Theme (Relationship) landmarks are often translated by mellan and mellom, as in (13), with $88 \%$ translated by both.

(13) His erratic marital status made a relationship between us inadvisable from my point of view, but I still eyed him with interest. (SG1)

SW: Hans komplicerade äktenskapliga situation gjorde ett förhållande mellan oss otillrådligt ur min synvinkel men jag sneglade fortfarande på honom med intresse. (SG1TS)

NW: Hans uoversiktlige sivilstand gjorde et forhold mellom oss utilrådelig på alle måter, men jeg hadde fremdeles en viss interesse for ham. (SG1TN) 
Theme (Comparison) landmarks are also often translated by mellan and mellom, as in (14), with $71 \%$ translated by both.

(14) There isn't any distinction between work and play. (JSM1)

SW: Det är ingen skillnad mellan arbete och lek. (JSM1TS)

NW: Det er ikke noe skille mellom arbeid og lek. (JSM1TN)

Setting (Time) landmarks may either consist of points in time, as in (15), or of events, as in (16). 65\% of all temporal predications are translated by both forms.

(15) The coroner estimates he went into the water sometime between midnight and five A.M.. (SG1)

SW: Enligt rättsläkaren hamnade han $i$ vattnet någon gång mellan midnatt och fem i morse. (SG1TS)

$N W$ : Legen mener at han havnet $i$ sjøen mellom midnatt og klokken fem $i$ morges. (SG1TN)

(16) Between calls he glanced at the pile of personal stuff he had brought down from his old office two floors above. (FF1)

SW: Mellan samtalen sneglade han på högen av ..... (FF1TS)

NW: Mellom telefonsamtalene så han gjennom bunken av ... (FF1TN

Scale landmarks are the predications least likely to be translated by both mellan and mellom, with just over $50 \%$ translated by both.

(17) The speed of one wolf was recorded at between 15 and 30 miles an hour for a distance of 12 miles, after which the animal had to slow down to a trot. (DM1)

SW: En varg klockades för mellan 25 och 50 kilometer i timmen över 20 kilometer, varefter den måste övergå $\mathrm{l}$ långsammare trav. (DM1TS)

NW: En ulv ble målt til mellom 25 og 50 kilometer over en distanse på 20 kilometer, hvoretter den måtte sette ned tempoet til trav. (DM1TN))

As for Experiencer landmarks, 75\% of the tokens are translated by both forms, as illustrated in (18).

(18) Celia immediately sensed an antagonism between herself and the director of research which would persist into the future. (AH1)

SW: Celia anade omedelbart en fiendskap mellan forskningschefen och henne själv som skulle kvarstå framöver. (AH1TS)

NW: Celia følte motsetningsforholdet mellom henne og forskningssjefen, og hans avvisende holdning forandret seg ikke i fremtiden. (AH1TN)

Two of the three occurring tokens of the Distribution landmarks are translated by both, as in (19).

(19) She always gave them a packet of Clarnico Iced Caramels when she came to the house and she made sure that the white and pink ones were divided evenly between them, even though they tasted the same. (RDO1)

SW: Hon gav dem jämt ett paket Clarnico glaserade karameller när hon kom hem till dom och såg till att dom delade upp dom vita och skära jämnt mellan sig, trots att dom smakade likadant. (RDO1TS)

NW: Hun hadde alltid med seg en pakke Clarnico glaserte karameller når hun kom og hun passet på at de delte de rosa og hvite broderlig mellom seg, selv om de smakte helt likt. (RDO1TN) 
Figure 2 contains details of the percentages of the various sorts of landmark that are coded by both mellan and mellom. The percentage of the total number of tokens that are so translated is just over $73 \%$, thus confirming our initial hypothesis that there we would find a considerable degree of overlap between the two default prepositions.

FIGURE 2

Percentage of tokens of each landmark type translated by both mellan and mellom

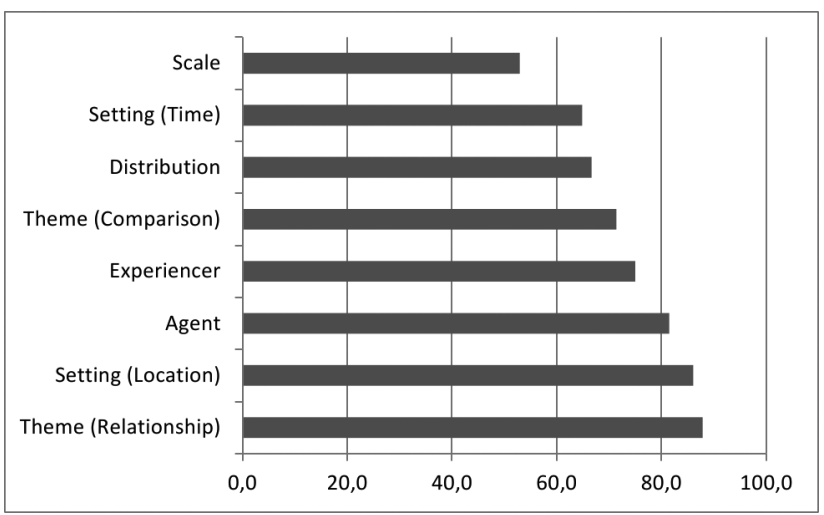

Having established this overlap, we turn now to those tokens which make use of other prepositions (in 4.2.) or of non-prepositional constructions (in 4.3.).

\subsection{Translations by other prepositions}

This category where the English between is rendered by another preposition or prepositional phrase accounts for a relatively small number of the total set of translations, with 24 occurrences in Swedish and 25 in Norwegian. Eight of these occurrences overlap, as in (20) where the cognate preposition $\underline{\mathrm{i}} / \mathbf{i}$ (in) is used in both translations. Note that in both translations the definite article is postposed to the noun meaning 'crossfire' (Swedish korselden, Norwegian ildlinjen, literally line of fire) In English the use of the definite article with 'crossfire' would also have triggered the preposition in rather than between.

(20) Will was too young to be at risk - in this community, unlike the black ones across the veld where no-one was too young to be out in the streets, caught between crossfire. (NG1)

SW: Will var för liten för att vara i riskålder - $i$ deras samhälle, i motsats till de svarta samhällena på andra sidan velden där ingen var för ung för att vara ute på gatorna, fängas i korselden. (NG1TS)

NW: Will var for ung til å vere utsatt innenfor deres egen gruppe, i motsetning til de svarte på den andre siden av veld'en, hvor ingen var for liten eller for ung til å vore ute i gatene, i ildlinjen. (NG1TN)

In Swedish the picture is quite diversified in that 11 different prepositions are used, including med (with), av (of), till (to), i (in), mot (against), inför (before), as in (21), and a few more. Note that the Norwegian translation in the example below (21) 
features the preposition mellom, which moreover occurs quite frequently, 11 times, in tokens translated into Swedish by a variety of prepositions.

(21) He dealt the menus out and left us to greet another couple, and we dithered enjoyably between lamb stuffed with herbs, daube, veal with truffles and an unexplained dish called the fantaisie du chef. (PM1)

SW: Så delade han ut matsedlarna och bröt upp för att ta emot ett annat par, och vi njöt av vårt vankelmod inför örtspäckat lamm, aladåb, kalv med tryffel och en rätt som utan närmare förklaring kallades fantaisie du chef. (PM1TS)

NW: Han ga oss menyene og forlot oss for å hilse et nytt par velkommen, og vi moret oss med å velge mellom lammestek med urter, lapskaus, kalv med trøfler, og en rett som bare ble kalt "fantaisie du chef." (PM1TN)

The translation category featuring other prepositions in Norwegian is less diversified compared to Swedish in that only seven different prepositions are used, the most common of which is fra...til, meaning from...to (11 out of 25 occurrences in this group).The overwhelming majority of the Norwegian cases featuring another preposition have mellan in their Swedish counterpart. There are in all 15 such instances. In nine of these cases mellan corresponds to fra....til as in (22).

(22) Some double stars are so close that they touch, and starstuff flows between them. (CSA1)

SW: Vissa dubbelstjärnor ligger så nära varandra, att de snuddar varandra och stjärnmateria flödar mellan dem. (CSA1TS)

NW: Enkelte dobbeltstjerner står så noer hverandre at de berører hverandre, og stjernestoffet bølger fra den ene til den andre og tilbake igjen. (CSA1TN)

As for the semantics, most of the landmarks translated by prepositions other than mellan/mellom code Setting in the original texts. There are 12 tokens of Setting (Location), as in (23), in which both translators employ the default equivalent of English through, and nine of Setting (Time). Apart from Theme (Comparison) which is translated in this way into at least one of the languages a total of seven times, the remaining landmarks have a frequency of less than three.

(23) The walls are made from loosely constructed planks between which the sunlight streams. (LT1)

SW: Själva bostaden består av ett litet hus med tak av bananblad och väggar av plank som frikostigt släppte in solskenet genom springorna. (LT1TS)

NW: Veggene består av løst sammenspikrete bord, og sollyset strømmer inn gjennom sprekkene. (LT1TN))

Having discussed the instances where alternative prepositions or prepositional phrases are employed, we now turn to the translations featuring non-prepositional constructions (denoted as divergent).

\subsection{Translations by divergent constructions}

Divergent translations are found 31 times in the Swedish and 16 times in the Norwegian translations. Seven of these cases are overlapping, that is, divergent in both languages. Of these seven tokens, two contain Agent landmarks in the original. The translations either employ adverbials coding cooperation such as tillsammans/ sammen (together) in (24 SW/NW) and (25 SW) or a reciprocal pronoun such as hverandre (each other) in (25 NW). 
(24) Between them, Challacombe and Mills put the business with Pauline on an idealistic footing. (RF1)

SW: Tillsammans placerade Challacombe och Mills .... (RF1TS)

NW: Sammen ga Challacombe og Mills ..... (RF1TN)

(25) She and Ryan between them cope with the baby. (PDJ1)

SW: Och tillsammans klarar hon och Ryan av babyn. (PDJ1TS)

NW: Hun og Ryan hjelper hverandre med den lille. (PDJ1TN)

Another translation strategy chosen when the landmark of between is an Agent, is to code it as the subject of the predication that is modified by the between phrase in English, as in the Swedish translations in (26) - lit. 'If these two bodies disagree' (literally 'are disagreed') - and (27) - lit. 'Okay, she and Arthur had intercourse.'

(26) In case of disagreement between these two bodies .... (AEEA1)

SW: Om dessa två organ är oeniga .... (AEEA1TS)

NW: Ved uenighet mellom de to organene .... (AEEA1TN)

(27) Okay, okay, intercourse took place between her and Arthur and very nice too. (FW1) SW: Okay, hon och Arthur hade samlag .... (FW1TS)

NW: OK, OK, samleie fant sted mellom henne og Arthur .... (FW1TN)

The same translation strategy may be chosen when the landmark of between is an Experiencer as in $(28 \mathrm{NW})$ which literally reads as 'even if they personally were not on the same wavelength,' and in (29), in which the landmark is encoded both as the subject and an adverbial in a relative clause in both translations - the translations of this example are 'one of the first sweet intimate discoveries they made about each other' (SW) and 'one of the first good things they discovered in each other' (NW).

(28) ... even if there was no personal empathy between them. (FF1)

SW: ... även om det inte fanns någon personlig förståelse dem emellan. (FF1TS)

NW: ... selv om de ikke personlig var på bølgelengde. (FF1TN)

(29) One of the early sweet intimacies between them .... (NG1)

SW: En av de första ljuva intima upptäckterna de gjorde om varandra ... (NG1TS)

NW: En av de første gode tingene de oppdaget hos hverandre .... (NG1TN)

Just as Agent and Experiencer landmarks can be coded by translators as Subjects, Theme landmarks may be coded as Objects, as in $(30 \mathrm{NW})$ which translates as 'In his thoughts he started to associate sex and death.'

(30) An early association between death and sex arose in him (RF1)

SW: En tidig koppling mellan död och sex började göra sig påmind inom honom. (RF1TS)

NW: I tankene begynte han å assosiere sex og død. (RF1TN)

These seven tokens, (24) to (30), illustrate just a few of the many divergent forms employed by the translators. Apart from these, there are a number of other divergent forms such as relative clauses which are employed to code the landmarks of various types of between predications, especially by Swedish translators, as illustrated in (31 SW), which reads as 'Why was Harry not at home to receive the first blow when she was exposed to these painful situations?' 
(31) Harry, she felt, ought to stand between her and these embarrassments. (FW1) SW: Varför var inte Harry hemma för att ta första stöten när hon utsattes för dessa pinsamma situationer? (FWITS)

NW: Hun syntes Harry burde demme opp mellom henne og disse kjedelighetene. $(F W 1 T N)$

To sum up this section on the translation equivalent of English between and the translation parallels, we have seen that there is a great deal of overlap between Swedish mellan and Norwegian mellom. Egan (2013a) also found a significant degree of overlap (56\%) between English between and French entre in translations of Norwegian mellom. The 'betweenness' relationship is a relatively simple concept in that the landmark consists of two and two points only. It may well be that this relatively simple profile motivates its similar coding in various languages. This similar coding simplifies the task of the translator who often has a felicitous translation equivalent to hand. In the next section we investigate the extent of similar codings in the two languages in cases where they do not translate between.

\section{Mellan and mellom translating sources not containing between}

Having established that Swedish mellan and Norwegian mellom are the default options for translators of English between, we now proceed to examine in the translated texts occurrences of these two prepositions which do not correspond to a token of between in the English originals. There are 128 such tokens in Swedish and 125 such tokens in Norwegian. Examples where two translators use these cognate prepositions to translate one and the same source token may be taken as stronger evidence for the semantic overlap in the meaning of the Swedish and Norwegian prepositions, than translations of source tokens containing between, given the fact that mellan and mellom represent the default translation equivalents of the latter. Tables 2 and 3 contain the correspondences in the original English texts of mellan and mellom where this source is not between. In both tables we show the four most common congruent correspondences.

\section{TABLE 2}

Tokens per semantic category of Swedish mellan not translating between

\begin{tabular}{|l|c|c|c|c|c|c|c|c|}
\hline English original & of & through & from & in & Other prep. & Divergent & $\varnothing$ & Total \\
\hline Setting (Location) & 1 & 17 & 3 & 7 & 11 & 10 & 1 & 50 \\
\hline Theme (Comparison) & 5 & & & 1 & 1 & 9 & 1 & 17 \\
\hline Agent & & & & & 5 & 5 & & 10 \\
\hline Theme (Relationship) & 11 & & 1 & & 4 & 15 & & 31 \\
\hline Scale & 1 & & 2 & & & 2 & & 5 \\
\hline Experiencer & & & & & & 1 & 1 & 2 \\
\hline Setting (Time) & 2 & & 4 & & 1 & 5 & & 12 \\
\hline Distribution & & & & & 1 & & & 1 \\
\hline Total & 20 & 17 & 10 & 8 & 23 & 47 & 3 & 128 \\
\hline
\end{tabular}


TABLE 3

Tokens per semantic category of Norwegian mellom not translating between

\begin{tabular}{|l|c|c|c|c|c|c|c|c|}
\hline English original & among(st) & of & through & in & Other prep. & Divergent & $\varnothing$ & Total \\
\hline Setting (Location) & 13 & & 13 & 9 & 9 & 15 & 5 & 64 \\
\hline Theme (Comparison) & & 5 & & & 5 & 13 & & 24 \\
\hline Agent & 4 & 2 & & & 3 & 7 & 1 & 17 \\
\hline Theme (Relationship) & 1 & 8 & & & & 6 & & 14 \\
\hline Scale & & & & & & 2 & & 2 \\
\hline Experiencer & & 1 & & & & 1 & & 2 \\
\hline Setting (Time) & & & & & 1 & 1 & & 2 \\
\hline Total & 18 & 16 & 13 & 9 & 18 & 45 & 6 & 125 \\
\hline
\end{tabular}

One point that emerges at once from the data in Tables 2 and 3 is the relatively small number of tokens, marked ' $\varnothing$ ' in the tables, in which the translator adds a predication of 'betweenness' which is lacking in the original text, marked $\varnothing$ in the tables. (32) is an example of this practice from Norwegian, (33) from Swedish.

(32) Wilf longed to hold those fingers. (ST1)

SW: Wilf längtade efter att hålla dessa fingrar. (ST1TS)

NW: Wilf skulle gjerne holdt fingrene hennes mellom sine egne. (ST1TN)

(33) She truly didn't know, and it had come to be understood that she was not to ask. (GN1)

SW: Hon hade absolut ingen aning, och det var underförstått mellan dem att hon inte fick fråga. (GN1TS)

NW: Hun hadde ikke den ringeste anelse, og det var underforstått at hun ikke skulle spørre. (GN1TN)

The Norwegian translation in (32) is a faithful rendition of the English original but adds the underlined words which may be translated as 'between his own.' This is a clear instance of explicitation in the sense of Blum-Kulka (1986). Becher (2010) defines explicitation as "the verbalization of information that the addressee would (most probably) be able to infer from the context, her world knowledge or from other inferential sources if it were not verbalized" (Becher 2010: 3). Given a situation in which one person holds the hands of another person, the default interpretation is that they use their hands to do so. Nevertheless, the Norwegian translator has decided to make this default interpretation explicit.

Similarly in (33) in which the text is about a couple and something is said to be understood, the default interpretation of the English original is that it is understood between the two people in question. Any other reading could only leave the producer of the statement as open to a charge of defaulting on Grice's maxim of quantity (Grice 1975). Yet the Swedish translator adds the underlined phrase, meaning 'between them.' It is worth pointing out that there are only three such tokens in the Swedish data as opposed to 29 instances where the between in the original text is not translated. There certainly does not seem to be a general tendency on the part of translators of these texts to make the 'betweenness' relationship more explicit. ${ }^{9}$ This paucity of examples of explicitation is in line with what might be expected given the criticism of the notion in recent years by scholars such as Becher (2011b: 27-28), who argues that it is unmotivated, unparsimonius and vaguely formulated. 
Leaving aside the tokens labelled ' $\varnothing$,' we see that in a majority of cases in both Swedish and Norwegian, the translations are congruent rather than divergent, insofar as the phrase containing mellan/mellom corresponds to a phrase containing another preposition in the original texts. The two languages differ somewhat, however, with respect to the prepositions in question. Whereas among(st) is the most common English form translated by Norwegian mellom, there are only seven tokens of mellan in Swedish corresponding to among(st). Indeed, there are four prepositions that are more common as sources of Swedish mellan. These are of, through, from and in.

32 of these 125 tokens of Norwegian mellom and 128 tokens of Swedish mellan share a common source. Eleven of these tokens diverge from the English original in introducing a preposition phrase where none exists in the source texts. In the remaining 21 tokens mellan/mellom correspond to a preposition in the source. The most common of these prepositions is of, represented by seven tokens, through, with five tokens and among, with four. We will look briefly at each of these correspondences in turn. To begin with the divergent translations, five of these correspond to hyphenated pairs in the source texts, as in (34).

(34) East-West suspicions have erected a visible barrier...... (CS1)

SW: Den ömsesidiga misstänksamheten mellan öst och väst har upprättat en synlig barriär... (CS1TS)

NW: Mistenksomhet mellom øst og vest har reist en synbar skranke.... (CS1TN)

The phrase East-West suspicions has been translated into both languages as 'suspicions between East and West.' Similarly, The Iran-Iraq war (CS1) is translated into both as 'the war between Iran and Iraq,' the Sino-Soviet split (MAW1) as 'the split between China and the Soviet Union' and U.S.-British relations (AH1) as 'relations between England and the U.S.' We can tentatively conclude that neither Swedish nor Norwegian favour coding 'betweenness' relationships by means of hyphens.

Of the remaining six divergent tokens, three contain the noun choice in the source text, all three being translated by a phrase meaning 'choose between' as in (35).

(35) At 7.40 she woke Harry and offered him a choice of shirts. (FW1)

SW: Klockan 7.40 väckte hon Harry och lät honom välja mellan ett antal skjortor. (FW1TS)

NW: Ti over halv åtte vekket hun Harry og gav ham flere skjorter å velge mellom. (FW1TS)

The preposition of, which occurs in (35) is also the preposition (other than between) that most frequently results in translation by both mellan and mellom. Common to all eight of these phrases, one of which is cited as (36), is that the use of between in the original in place of of would result in an equally idiomatic expression in English. ${ }^{10}$

(36) It is, in a way, the opposite of Chaos. It implies the deep interconnectedness of all things. (CSA1)

SW: Det antyder det djupa sammanhang som finns mellan alla ting. (CSA1TS)

NW: Det uttrykker på en måte det motsatte av kaos, og står for sammenhengen mellom alle ting. (CSATN)

Both translations contain a noun (sammanhang/sammenheng) corresponding to connection in English and the choice of this noun triggers the 'between' prepositions. The same point applies to the nouns corresponding to interplay (OS1), samspill 
in Norwegian and samspel in Swedish, which trigger 'between' prepositions, rather than av (of) prepositions. Similarly marriage of (ABR1) is translated by the equivalents of 'marriage between' and balance of (CS1) by the equivalents of 'balance between.' We may conclude (provisionally) that when the highly polysemous preposition of codes a 'betweenness' relationship, it is likely to be translated into Norwegian and Swedish by mellom and mellan.

The second most frequent preposition translated by both mellan and mellom is through. This preposition is most commonly translated into Swedish and Norwegian by genom/gjennom. However, both of these tend to denote a path that enters into and exits from a container. In English, on the other hand, motion through can denote motion that follows a path in gaps between several landmarks. Thus in (37) the use of genom/gjennom rather than mellan/mellom would imply that the Figure (in the sense of the entity that is moving in a predication of motion, see Talmy 2000) actually stepped in the puddles.

(37) and picking their way with distaste through the puddles on the pavement (PM1) SW: De kryssar med avsmak mellan vattenpölarna på trottoarerna. (PM1TS) NW: Så tar de seg forsiktig frem mellom søledammene på fortauet med sterkt misbilligende ansiktsuttrykk.(PMTN)

In (37) the Swedish and Norwegian Figures (see Talmy 2000) move between the puddles. Of course, this is what the English Figures do, too, but in the English text through implies 'between' in a way genom/gjennom do not. The exact same motion predication pick one's way through occurs in another text, ST1, with the landmark the women and two translations in which the Figure picks her way between rather than through them. If the Swedish and Norwegian translators had chosen to employ genom/gjennom rather than mellan/mellom they might have been understood to imply that the women in question were transparent. Two other tokens code perception rather than movement. In both of these through in the English source texts does not presuppose a transparent Ground. Thus, in he peered through his fingers (SK1) his line of vision is actually a gap between his fingers and the Swedish and Norwegian translators code it as such. (See Egan 2012 for more on the Norwegian translation equivalents of through).

The only other preposition to occur more than once as a source for mellan/mellom is among. Both Swedish and Norwegian contain a preposition bland/blant that may be considered the default translation equivalent of among (see Rawoens and Egan 2014). Contrasting among and between Lindstromberg (2010: 94; emphasis in the original) writes: "One sometimes hears that we should use AMONG when there are more than two Landmarks and BETWEEN when there are exactly two. [...] this is not always true." Even less is this true of mellan/mellom which frequently occur with more than two landmarks, as in (38).

(38) And then the pools, long deep gullies among the reefs. (ABR1) SW: Och sedan gölarna, långa, djupa klyftor mellan reven. (ABRTS) $\mathrm{NW}$ : Og så kulpene, lange, dype skar mellom revene. (ABRTN)

In (38) there are more than two reefs, given that there is more than one pool. According to Lindstromberg (2010: 94) the difference between the English prepositions among and between when used with multiple landmarks is that the former tends to denote location at various points in the middle of a set of objects, while the latter 
tends to denote location in the middle of pairs of objects. This difference is not equally prominent, if indeed it is present at all. Having said that, one may perhaps pick up a hint of the distinction in (39), in which the Norwegian translator's choice of the 'between' preposition may carry overtones of enclosure absent from the Swedish translation which retains the 'among' predication of the original text.

(39) I shut myself up in my room, safe among familiar schoolbooks. (NG1)

SW: Jag stängde in mig i mitt rum, i säkerhet bland välbekanta skolböcker. (NG1TS)

NW: Jeg lukket meg inne på rommet mitt, mellom trygge, velkjente skolebøker. (NG1TN)

While mellom as a translation of among is more common in the Norwegian texts than mellan is in Swedish, the opposite is the case for from, often combined with to. In tokens predicating Setting (Time) as in (40), Setting (Location) as in (41) and Scale as in (42), the Norwegian translator retains the 'from $x$ to $y$ ' coding of the original, while the Swedish translator prefers 'between $\mathrm{x}$ and $\mathrm{y}$ '’

(40) In the two decades from 1960 to 1980 .... (LT1)

SW: Mellan 1960 och 1980... (LT1TS)

NW: I perioden fra 1960 til 1980... (LT1TN)

(41) In the centre of Kempen lies Nijlen astride the main road and rail lines from Lier to Herentals. (FF1)

SW: Mitt i Kempen-distriktet ligger Nijlen vid landsvägen och järnvägen mellan Lier och Herentals. (FF1TS)

NW: Midt i Kempen ligger Nijlen tvers overfor hovedveien og jernbanelinjen fra Lier til Herentals. (FF1TN))

(42) The titles of the books he wrote range from Astronomy to On Freedom from Pain. (CSA1)

SW: Titlarna på de böcker han skrev omspänner allt mellan Astronomi och Om frihet från smärta. (CSA1TS)

NW: Tittelen på de bøker han skrev spenner fra Astronomi til Frihet fra smerte. (CSA1TN)

One final difference between the two languages to emerge from a comparison between the data in Tables 2 and 3 that calls for an explanation is the much greater number of translations containing mellan than mellom in the coding of Theme (Relationship) predications. One such example is (43).

(43) The relationship is established by exclaiming, "How much better the world would be if less money were spent on arms, and much more on economic and social development!" (CS1)

SW: Man skapar en förbindelse mellan "nedrustning" och "utveckling" genom att utropa: "Hur mycket bättre skulle inte världen vara om mindre pengar användes till vapen och i stället mycket mer till ekonomisk och social utveckling!" (CS1TS)

NW: Forholdet anskueliggjøres ved følgende utbrudd: "Hvor meget bedre ville det ikke ha voert $i$ verden dersom det ble brukt mindre penger til våpen og langt mere penger til økonomisk og sosial utvikling." (CS1TN)

In (43) the Swedish translator has added a phrase meaning 'between disarmament and development' to the word förbindelse, meaning relationship. The Norwegian translator has not felt the need to spell out the nature of the relationship, just employ- 
ing the word forholdet, also meaning relationship. Note that the anaphoric use of the definite article with relationship in the English original guarantees that the reader will be able to identify the relationship in question without further help. It is impossible to know why the Swedish translator opted for explicitation here. Somewhat different is the case of (44) in which both translators opt for a divergent translation, although only the Swedish translator employs a 'between' preposition.

(44) The disasters were directly related to failures in development. ( LT1)

SW: Det fanns ett direkt samband mellan katastroferna och felutveckling. (LT1TS) [There was a direct link between the catastrophes and the unsuccessful development]

NW: Katastrofene sto i direkte sammenheng med svikt i utviklingen. (LT1TN)

[The catastrophes stood in a direct relationship with the failure in development]

As can be seen from the literal translations in (44), neither of the translators has opted for a congruent translation. The Norwegian translator follows the order of the original more closely, only substituting 'stood in a direct relationship with' for 'were directly related to.' The Swedish translator opts instead to predicate the existence of a direct link before specifying the parties between whom the link obtained. Unlike in the case of (43), however, no explicitation is involved in the translation.

\section{Summary and conclusion}

This paper has given an account of a contrastive study using translation data, taking the codings of the semantic category 'betweenness' by means of the preposition between in English source data as the starting point and tertium comparationis for the analysis of Swedish and Norwegian translations.

In the first part of the study we distinguished eight main senses of the 336 tokens of English between. We based our classification on the semantic role of the landmark of the preposition. Amongst these, the landmark Setting (Location) sense outnumbered the other categories. Following the description of the semantics of the preposition between based on these occurrences, we set aside the English source texts and proceeded to analyze the Swedish and Norwegian translations (there were 336 tokens in our material that were translated into both languages). We hypothesized that we would find a considerable degree of overlap between the two default translation prepositions mellan in Swedish and mellom in Norwegian. The analysis confirmed this hypothesis, showing an overlap of just under $80 \%$ for the two forms. In other words, given the existence of a syntactically congruent translation equivalent, both sets of translators overwhelmingly opted to use this form. The figure of $80 \%$ may be compared to the overlap of just 34\% in the case of the cognate prepositions Swedish bland and Norwegian blant in translations of English among(st), according to Rawoens and Egan (2014).

Having studied the Norwegian and Swedish prepositions in tokens translating between, we turned our attention to tokens of mellan and mellom, which do not correspond to between in the original texts. We found that there were very few cases of pure explicitation, by which we mean the spelling out of information only implicit in the source. Although over a third of the translations into both languages are divergent in form, insofar as their source does not contain a prepositional phrase, 
these tokens instantiate rephrasing or paraphrasing rather than explicitation or addition. We found that the two sets of translators employed mellan and mellom in translations of the exact same sources in over a quarter of these translations of tokens not containing between. Although there is no established standard against which to evaluate this overlap, it must nevertheless be considered a strong indication of the extent of the resemblance between the two languages in their coding of 'betweenness' relationships. Differences between the languages, as represented in these two sets of translations, include a greater tendency on the part of the Norwegians to encode an 'among' predication as a 'between' one, and a greater tendency on the part of the Swedes to substitute a 'between' predication for a 'from... to' one. Finally we noted that the Swedish translators were more likely to use mellan to code the sort of predication we have termed 'Theme (Relationship)' than the Norwegians, without our being in a position to suggest any explanation as to why this should be so.

We have seen that there is a considerable degree of overlap between Swedish mellan and Norwegian mellom not only in translations of tokens containing the English preposition between, but also of tokens not containing this preposition. Egan (2013a) also found a significant degree of overlap (56\%) between English between and French entre in translations of Norwegian mellom. Moreover, the overlap between the two prepositions pertains in more than $50 \%$ of occurrences of all eight types of landmark studied. In addition, Egan (2013b) demonstrated on the basis of translations from Norwegian into English, French and German, that encodings of betweenness are more similar, cross-linguistically, than are encodings of throughness. The present study not only reinforces this conclusion with respect to the degree of crosslinguistic similarity in the coding of the concept of betweenness, but also shows that it is much more similar, at least in Swedish and Norwegian, than the related concept of amongness.

To conclude, we would suggest that the sort of 3-text approach employed in our study could with profit be applied to other linguistic phenomena. It allows the researcher access to data that is not retrievable from ordinary 2-text translation corpora. Such corpora could, for instance, never provide us with the sort of data we examined in our discussion of the overlap of the two Scandinavian prepositions. We would also maintain that the original source of the two sets of translations which are being compared makes for a much sounder tertium comparationis than texts in comparable corpora, where one can never be certain that one is dealing with efforts on the part of the language users to encode the same semantic concepts. We are conscious that these may seem rather large claims to make on the basis of a very limited body of research, but are nonetheless confident that future studies will reinforce our impression of the usefulness of this method.

\section{ACKNOWLEDGMENTS}

The authors wish to thank two anonymous referees for their constructive comments and suggestions. Gudrun Rawoens also expresses her gratitude to the Swedish Foundation Petra and Karl Erik Hedborgs Stiftelse for a research stay in Stockholm in June 2013 during which she collected most of her data. Thomas Egan wishes to thank the research group Arena for kultur- og språkfag at Hedmark University College for financing participation in conferences where some of the material in this paper was first aired. 


\section{NOTES}

1. See also Granger (1996: 38; 2003: 19-20), Johansson (1998: 4-5), Borin (2002: 2-5) and Laviosa (2002: 36-37) for reviews of the terminology used.

2. The same point applies of course, to 4-text, 5-text and 6-text corpora. For an example of the latter, see Viberg (2013).

3. For more information on the Oslo Multilingual Corpus (University of Oslo) see http://www.hf.uio. no/ilos/english/services/omc.

4. The corpora are accessible online (access account on demand). More info can be found on the respective web pages: http://www.sol.lu.se/engelska/corpus/corpus/espc.html (ESPC) and https:// www.hf.uio.no/ilos/english/services/omc (ENPC).

5. The reason this percentage is approximate is that the total number of tokens in the two corpora is not identical.

6. Given the bottom-up nature of our investigation we did not wish to have recourse to pre-wrapped dictionary definitions, as it were. This is not to imply that all of our eight classes may not be found in a good dictionary. Thus the five definitions in the New Oxford Dictionary of English account for seven of them, the exception being the sense we have labelled 'Distribution.'

7. The code refers to the work in the corpus the example is taken from. For a list and a description of the works included in the corpora see the respective corpus web pages.

8. In the two corpora both the Swedish and Norwegian translated tokens are labelled 'EEA1T,' the 'T' serving to indicate that they are translations of the original text labelled 'EEA1.' Following the practice of the compilers of the Oslo Multilingual Corpus we have added a letter to the corpora labels, an 'S' for Swedish and an 'N' for Norwegian.

9. See Cappelle (2012) for a discussion of the inability of the Explicitation Hypothesis to account for differences in his data in the coding of motion verbs in French and German originals and their English translations.

10. A Google search (on $4^{\text {th }}$ November 2013) returned just over a million hits for 'interconnectedness of' and 110,000 hits for 'interconnectedness between.'

\section{REFERENCES}

Aijmer, Karin and Altenberg, Bengt (1996): Introduction. In: Karin Aijmer, Bengt Altenberg and Mats Joh Ansson, eds. Languages in Contrast. Papers from a Symposium on Text-based Cross-linguistic Studies, Lund, 4-5 March 1994. Lund: Lund University Press, 11-16.

Aijmer, Karin, Altenberg, Bengt and Johansson, Mats (1996): Text-based contrastive studies in English. Presentation of a project. In: Karin Aijmer, Bengt Altenberg and Mats Johansson, eds. Languages in Contrast. Papers from a Symposium on Text-based Crosslinguistic Studies, Lund, 4-5 March 1994. Lund: Lund University Press, 73-85.

Altenberg, Bengt and Granger, Sylviane (2002): Recent trends in cross-linguistic lexical studies. In: Bengt Altenberg and Sylviane Granger, eds. Lexis in Contrast. Corpus-based approaches. Amsterdam/Philadelphia: John Benjamins, 1-48.

BECHER, Viktor (2011a): Explicitation and Implicitation in Translation; A Corpus-based Study of English-German and German-English Translations of Business Texts. Manchester: St. Jerome.

Becher, Viktor (2011b): When and why do translators add connectives? A corpus-based study. Target. 23(1):26-47.

BeCHer, Viktor (2010): Towards a more rigorous treatment of the Explicitation Hypothesis in translation studies. trans-kom 3(1):1-25.

Blum-Kulka, Shoshana (1986): Shifts of Coherence and Cohesion in Tranlsation. In: Juliane House and Shoshana Blum-KulKa, eds. Interlingual and Intercultural Communication. Tübingen: Gunter Narr, 17-35.

Borin, Lars (2002): ... and never the twain shall meet? In: Lars Borin, ed. Parallel Corpora, Parallel Worlds. Selected papers from a symposium on parallel and comparable corpora at Uppsala University, Sweden, 22-23 April, 1999. Amsterdam: Rodopi, 1-43.

CAPpelle, Bert (2012): English is less rich in manner-of-motion verbs when translated from French. Across Languages and Cultures. 13(2):173-195. 
Chesterman, Andrew (1998): Contrastive Functional Analysis. Amsterdam/Philadelphia: John Benjamins.

Egan, Thomas (2012): Through seen through the looking glass of translation equivalence: a proposed method for determining closeness of word senses. In: Sebastian Hoffman, Paul Rayson and Geoffrey N. Leech, eds. Corpus Linguistics: Looking Back - Moving Forward. Amsterdam: Rodopi, 41-56.

Egan, Thomas (2013a): Tertia comparationis in multilingual corpora. In: Karin Aijmer and Bengt Altenberg, eds. Advances in Corpus-based Contrastive Linguistics. Studies in honour of Stig Johansson. Amsterdam: John Benjamins, 7-24.

Egan, Thomas (2013b): Between and through revisited. VARIENG: Studies in Variation, Contacts and Change in English. 13. Visited 14.12.2015, <http://www.helsinki.fi/varieng/series/volumes/13/egan/>.

Gellerstam, Martin (1996): Translations as a source for cross-linguistic studies. In: Karin Aijmer, Bengt Altenberg and Mats Johansson, eds. Languages in Contrast. Papers from a Symposium on Text-based Cross-linguistic Studies, Lund, 4-5 March 1994. Lund: Lund University Press, 53-62.

Granger, Sylviane (1996): From CA to CIA and back: An integrated approach to computerized bilingual and learner corpora. In: Karin Aijmer, Bengt Altenberg and Mats Johansson, eds. Languages in Contrast. Papers from a Symposium on Text-based Cross-linguistic Studies, Lund, 4-5 March 1994. Lund: Lund University Press, 37-51.

Granger, Sylviane (2003): The corpus approach: a common way forward for Contrastive Linguistics and Translation Studies? In: Sylviane Granger, Jacques Lerot and Stephanie Petch-Tyson, eds. Corpus-based Approaches to Contrastive Linguistics and Translation Studies. Amsterdam/New York: Rodopi, 17-29.

Grice, Herbert Paul (1975): Logic and conversation. In: Peter Cole and Jerry L. Morgan, eds. Syntax and Semantics. Volume 3. New York: Academic Press, 41-58.

James, Carl (1980): Contrastive Analysis. London: Longman.

Johansson, Stig (1975): Papers in Contrastive Linguistics and Language Testing. Lund: Gleerups.

Johansson, Stig (1998): On the role of corpora in cross-linguistic research. In: Stig JoHansson and Signe OKsefjell, eds. Corpora and Cross-linguistic Research: Theory, Method, and Case Studies. Amsterdam: Rodopi, 3-24.

Johansson, Stig (2000): Contrastive Linguistics and Corpora. SPRIKreports. 3. Visited 14.12.2015, $<$ https://www.hf.uio.no/ilos/forskning/prosjekter/sprik/pdf/sj/johansson2.pdf>.

Johansson, Stig (2001): The German and Norwegian correspondences to the English construction type that's what. Linguistics 39(3):583-605.

Johansson, Stig (2007): Seeing through Multilingual Corpora: On the Use of Corpora in Contrastive Studies. Amsterdam: John Benjamins.

Johansson, Stig, Ebeling, Jarle and Oksefjell, Signe (2002): English-Norwegian Parallel Corpus: Manual. University of Oslo: Department of British and American Studies. Visited 14.12.2015, <https://www.hf.uio.no/ilos/english/services/omc/enpc/ENPCmanual.pdf>.

Krzeszowski, Tomasz P. (1990): Contrasting languages: The scope of contrastive linguistics. Berlin: Mouton de Gruyter.

Laviosa, Sara (2002): Corpus-based Translation Studies. Theory, Findings, Applications. Amsterdam: Rodopi.

LANGACKer, Ronald (1987): Foundations of Cognitive Grammar: Volume 1, Theoretical Prerequisites. Stanford: Stanford University Press.

Lindstromberg, Seth (2010): English Prepositions Explained: Revised edition. Amsterdam: John Benjamins.

Mauranen, Anna (2005): Contrasting languages and varieties with translational corpora. Languages in Contrast 5(1):73-92.

Rawoens, Gudrun (2008): Kausativa verbkonstruktioner i svenskan och nederländskan. En korpusbaserad syntaktisk-semantisk undersökning. Göteborgsstudier i nordisk språkvetenskap 11. Göteborg: Göteborgs universitet. 
Rawoens, Gudrun and Egan, Thomas (2014): Amid(st) and among(st): a contrastive approach. In: Lieven Vandelanotte, Kristin Davidse, Caroline Gentens and Ditte Kimps, eds. Recent Advances in Corpus Linguistics: Developing and Exploiting Corpora. Amsterdam/ New York: Rodopi, 207-228.

Talmy, Leonard (2000): Towards a Cognitive Semantics, Volume II: Typology and Process in Concept Structuring. Cambridge: The MIT Press.

TEUBERT, Wolfgang (1996): Comparable or parallel corpora? International Journal of Lexicography 9(3):238-264.

VIBERG, Åke (2013): Seeing the lexical profile of Swedish through multilingual corpora: The case of Swedish åka and other vehicle verbs. In: Karin Aijmer and Bengt Altenberg, eds. Advances in Corpus-based Contrastive Linguistics. Studies in honour of Stig Johansson. Amsterdam: John Benjamins, 25-56. 